\title{
American Association of Petroleum Geologists (AAPG)
}

\section{http://www.aapg.org}

American Association of Petroleum Geologists (AAPG) is an international organization for petroleum geologists and geoscientists with 30,000 members in 120 countries. Since its founding in 1917, AAPG's purpose has been to foster scientific research, to advance the science of geology especially as it relates to exploring for hydrocarbons, to promote technology and to inspire high professional conduct. International headquarters is in Tulsa, OK, USA.

\section{Publications}

AAPG publishes the BULLETIN, a technical journal recognized by industry and academia as the premier peer-reviewed publication for the exploration community; the EXPLORER, an awardwinning monthly newspaper with an editorial focus on the entire span of energy interests with emphasis on exploration and development; and more than 135 publications presenting the most current geoscience information available.

\section{Meetings}

In addition to the AAPG Annual Meeting which offers over 700 technical presentations and an exhibition of the latest in exploration technology and drawing an international audience, AAPG also conducts an International Conference and Exhibition beyond the U.S. shores. Both of these major meetings include field trips and short courses, affording the additional opportunities for exposure to the latest research and ideas.

Additionally, four to six research conferences on topical issues are held in various parts of the world each year (2002 scheduled conferences in Stavanger, Algeria, Sicily, Vancouver, Adelaide and Vail).

Also, in North America there are 4-5 meetings a year in each section to promote the dissemination of the most current geologic and technical advances for each area.

\section{Lectures}

Distinguished lectures are provided to associations and universities worldwide to speak on the latest geoscience thinking and technology. At least 14-15 lectures are made available for this program which is in contact with a cumulative audience of several thousand individuals annually.

Subjects range from sequence stratigraphy to $4 \mathrm{D}$ seismic, from global climate change to cutting edge geochemistry. The AAPG Visiting Geologist Program offers industry speakers to colleges and universities all over the world with a very wide variety of topics from creative thinking to career advice.

\section{Education}

AAPG has a comprehensive continuing education program to keep members current with the latest exploration tools and philosophies including 16-26 online distance learning modules. An additional 10 distance learning modules will be added this year.

\section{Digital Library}

AAPG has digitized all publications from 1917 to present and is now including member access to the BULLETIN library dating back to 1917. And AAPG has formed an alliance with other key geoscience associations to begin to build a worldwide digital library,

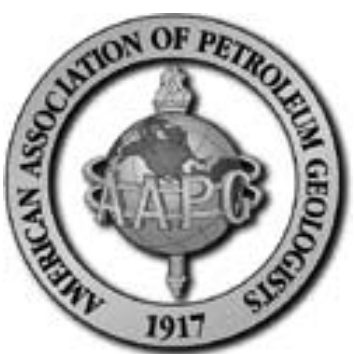

both for forward publishing and for archival digits. The vision is for the geoscientist to have on-line, seamless, searchability for all journals in the near future.

\section{Student Activities}

AAPG is committed to educating the young scientist of today with special training for students as well as educators.

Students Chapters have been formed in universities worldwide and have the benefit of a Lewis Weeks grant for field trip activities and travel to conferences. Graduate students can apply for $\$ 1,000$ to $\$ 2,000$ scholarships for field work. Student Expos are held 1-3 times a year as a forum to get recruiters together with students for internships and jobs. The advantage of these central Expos is that students from smaller universities have access to recruiters that ordinarily would not be available. A Virtual Student Expo is being developed to serve student members worldwide. Additionally, a Mentoring program has been developed to pair students and young professionals with older experienced geologists for one-on-one mentoring.

\section{Teachers Programs}

AAPG provides training for science teachers, sponsors the Teacher of the Year Program for Excellence in Earth Science teaching and is in cooperation with the Boy Scouts, Girl Scouts and 4-H on their national programs.

\section{Environmental Responsibility}

AAPG's Division of Environmental Geology publishes best practices and promotes responsible development of energy resources. Geologists, by nature, have a deep and sincere appreciation of the Earth and Earth processes. Their involvement in the extraction of resources is combined with the goal of sensitive and responsible development.

\section{Energy Minerals}

In addition to serving members involved in the development of conventional oil and gas resources, AAPG has a Division for geoscientists involved in coal, coal bed methane, unconventional gas resources, hydrates, uranium, and other energy minerals.

\section{Professional Affairs}

AAPG's Division of Professional Affairs seeks to assist the professional by providing a means for professional certification of petroleum geologists, coal geologists and petroleum geophysicists, promoting professsionalism and ethical standards and assisting with career planning.

\author{
Robbie Gries \\ President, $A A P G$ \\ Priority Oil \& Gas LLC \\ P. O. Box 27798 \\ Denver, CO USA 80227-0798 \\ Phone: +1-303-296-3435 \\ Fax: +1-303-296-3436
}

